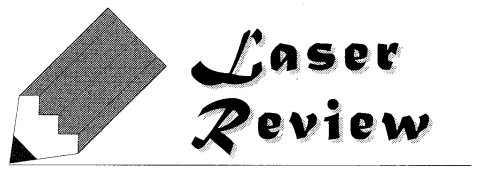

\title{
近接場CARS顕微鏡によるDNA分子イメージング
}

\author{
市村 垂生 ${ }^{1}$, 井上 康志 1,3 , 河田 聡 2,3 \\ 1 大阪大学大学院 生命機能研究科 ( T 565-0871 大阪府吹田市山田丘1-3) \\ 2 大阪大学大学院 工学研究科忘用物理学専攻 († 565-0871大阪府吹田市山田丘2-1) \\ 3 理化学研究所 (
}

\section{Near-Field CARS Microscopy for Molecular-Imaging of DNA}

\author{
Taro ICHIMURA, ${ }^{1}$ Yasushi INOUYE,,${ }^{1,3}$ and Satoshi KAWATA ${ }^{2,3}$ \\ ${ }^{I}$ Graduate School of Frontier Biosciences, Osaka University, 1-3 Yamadaoka, Suita, Osaka 565-0871 \\ ${ }^{2}$ Department of Applied Physics, Graduate School of Engineering, Osaka University, 2-1 Yamadaoka, Suita, Osaka 565-0871 \\ ${ }^{3}$ RIKEN, 2-1 Hirosawa, Wako, Saitama 351-0198
}

(Received September 28, 2005)

\begin{abstract}
Tip enhanced near-field scanning optical microscopy and coherent anti-Stokes Raman scattering (CARS) spectroscopy, a type of nonlinear Raman spectroscopy, have been successfully combined to image and analyze molecular distribution of nano-structures. Owing to the third order nonlinearity of the CARS process, the excitation of the CARS polarization is extremely confined to the end of the tip apex, resulting in high image contrast and high spatial resolution far beyond the diffraction limit of light. Our tip-enhanced CARS microscope visualized a deoxyribonucleic acid (DNA) network structure at a characteristic vibration-frequency $\left(1337 \mathrm{~cm}^{-1}\right)$ in the fingerprint region with a spatial resolution of $\sim 15 \mathrm{~nm}$.
\end{abstract}

Key Words: Near-field scanning optical microscopy, Nonlinear optical effect, Metallic probe tip, Local field enhancement, Coherent anti-Stokes Raman scattering (CARS)

1.はじめに

近接場光学顕微鏡は, 光の回折限界以下の空間分解能 で物質の，文字通り光学情報を取得できる顕微鏡であ る1). 光学情報とは, 吸収, 屈折, 散乱, 発光などの相互 作用を通して計測される, 試料の分子・結晶の組成や構 造といった物質情報を意味する，光学情報を計測するた めの様々な分光計測技術を顕微鏡と組み合わせることに より，物質情報をマッピングできるのである．原子分解 能で画像を提供してくれるSTMやAFMなど他のナノプ ローブ顕微鏡 2 に対して, 近接場光学顕微鏡の存在意義は そこにある．加えて，そもそも光は試料に対して優しい プローブであることから，生体分子などのソフトマテリ アルも非破壊で分析でき，生体内の環境(液中)でも使用で きる。それゆえ，生物分野では光学顕微鏡が広く使用さ れてきた. 近接場光学顕微鏡は, このような鬼力的な特 長を，そのままナノの世界に持ち込む。

種々の分光計測技術の中でもとくに分子振動分光 (ラマ ン散乱\&赤外吸収) は，試料を染色などの前処理なくその ままの状態で分子組成を分析できる。我々はこれまで に，先鋭な非開口金属プローブを用いた近接場光学顕微 鏡3)によるナノスケールラマン分光を提案, 実現してき
た4,5). 金属プローブ先端(チップ)における局在プラズモ ン励起を利用し, チップ下のナノ領域の分子のラマン散 乱を誘起するものである.チップ増強ラマン散乱 (Tip enhanced Raman scattering; TERS) と呼ばれ，これは，表面増 強ラマン散乱 (Surface enhanced Raman scattering; SERS) 6,7) を金属チップ先端で実現したことにほかならない. DNA などの生体分子 ${ }^{8)}$ や単層カーボンナノチューブ9)に代表さ れる最先端ナノ材料のナノラマン分析を実現し, ラマン 分光法をナノの世界に導入するに至った。最近では他の 研究グループからも報告があり ${ }^{10,11)}$, 近接場光学顕微鏡の 分野で今最もホットなトピックの1つである.

この金属チップ増強型の近接場ラマン分光顕微鏡を高 空間分解能化し, より微小な構造の観察に応用したい. このためには，ラマン分極をさらに空間的に閉じ込める 必要がある。本稿で紹介する研究では，自発ラマン散乱 の代わりに非線形ラマン散乱を利用し，その非線形性に より空間分解能の向上を図る12,13). 非線形のラマン散乱と してコヒーレントアンチストークスラマン散乱(CARS) 用いて近接場CARS顕微鏡を構築し, DNA分子13)や単層 カーボンナノチューブ12)のラマンイメージングを実現し た.とくに，DNAのナノネットワーク構造を，DNA塩基 分子に特徵的な指紋領域の振動モードにおいて，約 $15 \mathrm{~nm}$ 
の空間分解能で可視化できた。本稿では，近接場CARS顕 微鏡の原理, 装置について述べ, このDNA分子イメージ ングの実験について概説する.

\section{2. 近接場CARS顕微鏡の原理}

波長以下の大きさの先鋭な金属プローブ先端に光を照 射すると, 先端のチップ近傍の微小領域に強い光場が生 成される3,14).チップの金属中の電子が入射光によって励 振されることによって起こる15)。これを局在表面プラズ モンといい，SERSにおける電磁気学的増強と同じ原理に 基づく6). この局所増強場で分子のラマン散乱を誘起する ことで，チップサイズ程度の微小領域のラマンスペクト ルが得られる(Fig. 1)。試料またはプローブを走査すれ ば，先端サイズ程度の空間分解能でのラマンイメージン グが可能となる $8,16,17$.

本研究で提案する近接場CARS顕微鏡では, 金属チップ の局所増強場でCARSを誘起する.CARSは三次の非線形 コヒーレントラマン散乱の一つで，二色の励起光の振動 数差 $\left(\omega_{1}-\omega_{2}\right)$ を試料分子に特徵的なラマン活性振動準位の 振動数 $\left(\Omega_{\text {Raman }}\right)$ に一致させ, 振動数が $\omega_{3}=\left(\omega_{1}-\omega_{2}\right)+\omega_{1}=$ $2 \omega_{1}-\omega_{2}$ のCARS分極(式 (1))を共鳴的に誘起する (Fig. 2 (a)) ${ }^{18)}$.

$$
P_{C A R S}^{(3)}\left(\omega_{3}=2 \omega_{1}-\omega_{2}\right)=\chi^{(3)} E_{1}\left(\omega_{1}\right) E_{2}^{*}\left(\omega_{2}\right) E_{1}\left(\omega_{1}\right)
$$

ここで， $\chi^{(3)}$ は非線形感受率， $E_{1}\left(\omega_{1}\right)$ や $E_{2}\left(\omega_{2}\right)$ はそれぞれ 励起場の $\omega_{1}$ と $\omega_{2}$ の振動数成分を表し, $E_{2} *\left(\omega_{2}\right)$ は $E_{2}\left(\omega_{2}\right)$ の 複素共役を表す。本来はべクトル式であるがここでは簡 単のためスカラー式で表現した。非線形感受率 $\chi^{(3)}$ は，一 般的に振動準位に関係する共鳴項 $\left(\chi_{R}{ }^{(3)}\right)$ と関係しない非 共鳴項 $\left(\chi_{N R}{ }^{(3)}\right)$ の和(式 $\left.(2)\right)$ で表される.

$$
\chi^{(3)}=\chi_{R}^{(3)}+\chi_{N R}^{(3)}=\frac{A}{\Omega_{\text {Raman }}-\left(\omega_{1}-\omega_{2}\right)-i \Gamma}+\chi_{N R}^{(3)}
$$

$A$ は振動強度を表す定数，「はバンド幅に相当する． $\chi_{N R}{ }^{(3)}$ は振動共鳴準位を経由しない過程からの寄与である。と

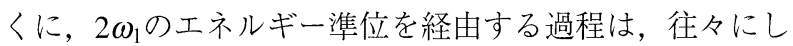

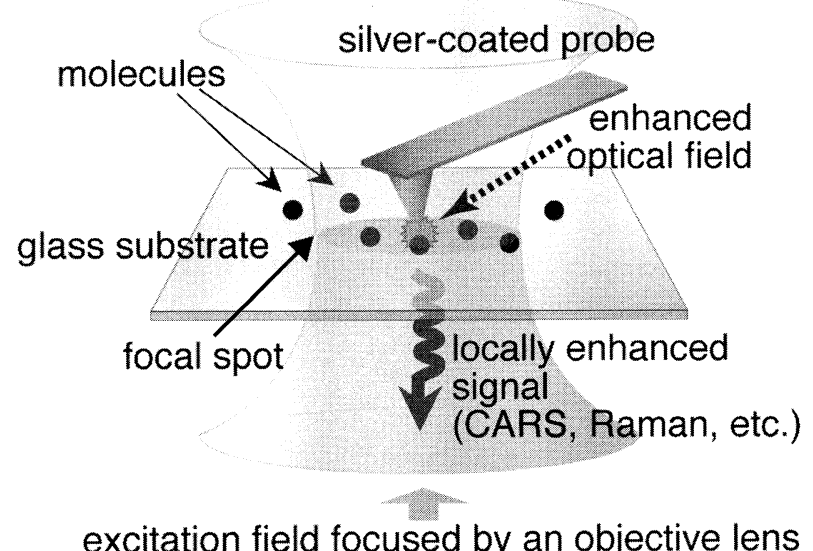

Fig. 1 Schematic illustration of local enhancement by a metallic probe tip. (a)
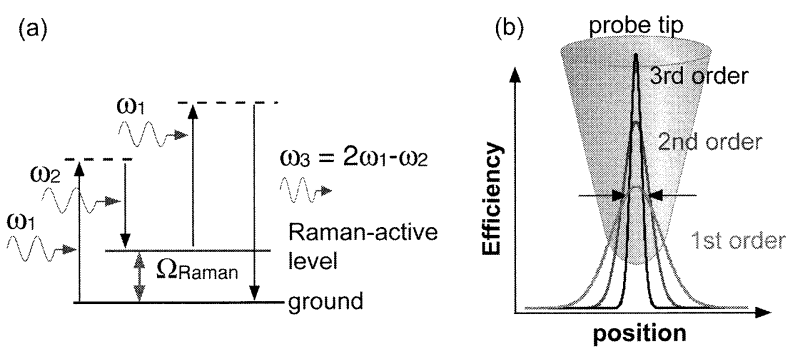

Fig. 2 (a) Energy diagram of the CARS process. (b) Spatial confinement of the excitation efficiency of highorder nonlinear effects.

て電子準位共鳴もしくは前期共鳴過程となるため ${ }^{18)}$, 最 も大きな寄与を与える.この分極による放射光がCARS光 であり， $\omega_{2}$ を掃引しながら $\omega_{1}-\omega_{2}$ に対してCARS光強度を プロットすれば，自発ラマンスペクトルと類似のCARSス ペクトルが得られる。自発ラマン分光法同様，分子種や 分子組成といった化学情報を取得できる。もちろん, 染 色などの前処理は必要ない，通常のCARS分光法において は，励起レーザー光を試料中で位相整合条件を満たすよ うな角度で交差させ, CARSを誘起する.これに対し, 金 属チップ先端などの局所領域でCARSを誘起する場合, 位 相整合条件は緩和される ${ }^{19)}$. CARS光の波長よりもはるか に小さい領域でCARS分極が同位相で誘起されるため, 励 起光の波数べクトルの向きに依存しなくなり, CARS光の 散乱パターンは孤立振動双極子のそれのように等方的に なる。このような考え方は，近年報告された(ファー フィールドの) レーザー走査CARS顕微鏡 20,21$)$ にも共通す る。ファーフィールドの系の場合, 高NAの対物レンズを 用いて励起光を広い立体角で強く集光することにより， 相互作用領域を波長サイズ以下に閉じ込めるものであっ た22,23) 、金属ナノチップによる局所増強はその極限形と言 える，以上のように，位相整合条件は，相互作用領域が 波長以下となる近接場CARS顕微鏡においては，考慮する 必要がなくなる。

金属チップでCARS分極を誘起するとき, CARSの三次 の非線形性により, CARS分極の誘起効率がチップ先端の さらに微小な領域に閉じ込められる。この効果は, 通常 のレーザー走査顕微鏡においては, 超分解を実現する1つ の方法として既に認知されている24,25).このことは, CARS誘起効率の空間分布 $\left(P_{\mathrm{CARS}}{ }^{(3)}\left(r, \omega_{3}\right)\right.$, （式 (1) に空 間座標を加えた))が，2色の励起場の空間分布の3次の積 $\left(E_{1}^{2}\left(r, \omega_{1}\right) E_{2} *\left(r, \omega_{2}\right)\right)$ で与えられることで説明される. レーザー走査顕微鏡においては, $E_{1}\left(r, \omega_{1}\right) や E_{2}\left(r, \omega_{2}\right)$ は 集光された励起場の分布を表すが，このとき， $P_{\mathrm{CARS}}{ }^{(3)}$ $\left(r, \omega_{3}\right)$ は2色の励起場に比べ狭い領域に閉じ込められるわ けである (Fig. 2(b)). 近接場CARSにおいても同様で, こ の場合 $E_{1}\left(r, \omega_{1}\right)$ や $E_{2}\left(r, \omega_{2}\right)$ はチップ近傍の電場分布を表 す。たとえば金属微小球と単一分子の系について考えて みる。それぞれ波長に対して十分小さいと仮定した場 合，誘起される分極を振動双極子で置き換えて表され る26). 外部からの光照射よって金属微粒子周りにできる 近接場の強さは，金属位置からの距離 $R$ の乗分の 1 , すな わち $1 / R^{3}$ に比例する。この近接場により励起されるCARS 
分極はその3乗，すなわち， $\left(1 / R^{3}\right)^{3}=1 / R^{9}$ に比例し， $1 / R^{3}$ に依存する通常のラマン (=自発ラマン)より, 狭い領域で 励起されることになる。実際に遠方で検出される信号 は，分子そのものからの直接の信号ではなく，むしろ金 属チップに再散乱された光であり,このCARS光に対して も距離に依存した因子がかけられる。そのため結局, CARSと自発ラマンはそれぞれ4乗と2乗に比例することに なるが，いずれにしてもCARSはラマンに比較して狭い領 域で誘起されることになる。

近接場CARSに扔ける増強効果はどうなるだろうか.こ こにも，非線形の効果がプラスに働く．励起場の各成分 はチップの金属によって, 局所的に増強される. 式(1)の 右辺の励起場全てに増強度がかかるため, 増強度は電場 のそれに比べて強くなる。ここでもやはり, 散乱場の増 強効果があるため, 結局増強効果を加えた近接場CARSの 分極は式(3)のように表される。

$$
\begin{aligned}
& P_{\text {CARS }}^{(3)}\left(\omega_{3}\right)=L\left(\omega_{3}\right) \\
& \quad \times\left\{\chi^{(3)}\left[L\left(\omega_{1}\right) E_{1}\left(\omega_{1}\right)\right]\left[L\left(\omega_{2}\right) E_{2}\left(\omega_{2}\right)\right]\left[L\left(\omega_{1}\right) E_{1}\left(\omega_{1}\right)\right]\right\} \\
& =L\left(\omega_{3}\right) L\left(\omega_{1}\right) L^{*}\left(\omega_{2}\right) L\left(\omega_{1}\right) \times\left[\chi^{(3)} E_{1}\left(\omega_{1}\right) E_{2}^{*}\left(\omega_{2}\right) E_{1}\left(\omega_{1}\right)\right](3)
\end{aligned}
$$

ここで, $L\left(\omega_{i}\right)(i=1,2,3)$ は局所場因子と呼ばれるもの で，ここではたとえばチップ先端でのそれぞれの波長で の増強度を表す。これに対して, 自発ラマンの場合は, そのラマン分極は以下の式(4)で表される.

$$
\begin{aligned}
P_{R S}^{(1)}\left(\omega_{2}\right) & =L\left(\omega_{2}\right)\left[\chi^{(1)} L\left(\omega_{1}\right) E_{1}\left(\omega_{1}\right)\right] \\
& =L\left(\omega_{2}\right) L\left(\omega_{1}\right) \times \chi^{(1)} E_{1}\left(\omega_{1}\right)
\end{aligned}
$$

ここで, $\chi^{(1)}$ はラマン散乱過程の線形感受率である。結 局, 増強度も自発ラマンに比べて高次となる。このこと は, 単純にCARS光の増強度が大きくなることに加え, ファーフィールドバックグラウンドの軽減にもつなが る。ファーフィールドバックグラウンドとは，レーザー 光を照射した領域のうちチップから離れた場所で誘起さ れるCARS/ラマン光のことで, 自発ラマンの実験において たびたび問題になってきた27). CARSにおいては, チップ 周辺で増強された近接場CARS光がファーフィールドバッ クグラウンドに比べて高コントラストで得られるので, 得られる像が解釈しやすくなる。

以上のように, 非線形効果であるCARSを用いることに よって, 自発ラマンと比較して, 空間分解能, 信号の増 強度, ファーフィールドバックグラウンドに対するコン トラストという3つの点において向上を期待できる。

\section{3. 近接場CARS顕微鏡のシステム}

近接場CARS顕微鏡システムを試作した (Fig. 3). 励起光 源として，2台のピコ秒モードロックチタンサファイア レーザー(繰り返し周波数 $~ 80 \mathrm{MHz}$ )を用いた。パルス幅 は約 $5 \mathrm{ps}$ であり,これは約 $4 \mathrm{~cm}^{-1}$ 程度のスペクトル幅に相 当する。このスペクトル幅は, 指紋領域に扔ける生体分 子の振動モードのバンド幅と同程度である。もし，フエ ムト秒レーザーのようなより短いパルスを用いれば，一

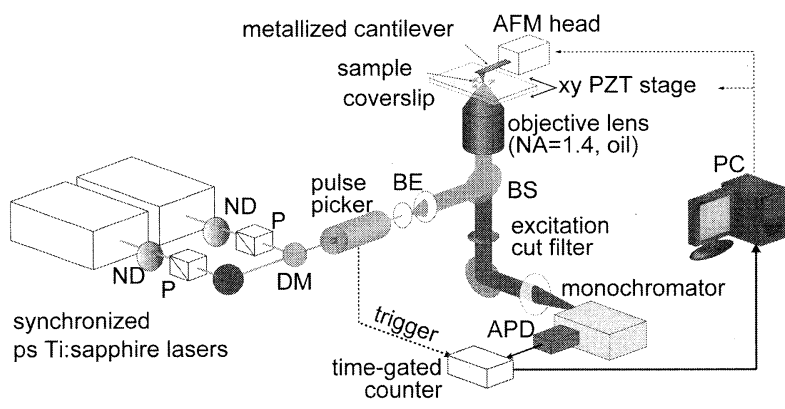

Fig. 3 An experimental system of tip-enhanced CARS microscopy. See the text for detail.

般的に非線形効果の誘起効率が向上するが，スペクトル 分解能は得られない。一方，ナノ秒レーザーを用いれば 高スペクトル分解能を達成できるが，信号強度が稼げな い. 高効率な振動分光イメージングを実現するために は, 今回用いた数ピコ秒程度のピコ秒レーザーが最適な 選択である。これら2本のピコ秒レーザーパルス列を時間 的抢よび空間的に重ね，原子間力顕微鏡 $(\mathrm{AFM})$ を搭載し た倒立顕微鏡に導入し, 対物レンズ $(\mathrm{NA}=1.4$, 油浸)によ り試料表面に集光した。プローブとして，AFM用のシリ コンカンチレバーに銀を $20 \mathrm{~nm}$ 真空蒸着したものを用い た。フォーカス内にプローブ先端を接触させ局所領域の CARS分極を誘起し，この散乱光を入射に使用した高NA 対物レンズで高い効率で集めた. CARS光は, 励起光除去 フィルターとモノクロメーターを通して, アバランシェ フォトダイオード $(\mathrm{APD})$ により光子計数した。また，パ ルスピッカーを顕微鏡の手前に配置し, パルスの繰り返 し周波数を $800 \mathrm{kHz}$ に下げた。これにより, 非線形効果の 効率を維持しながら試料やプローブに対する熱ダメージ を抑えた。また，APDのフォトンカウンターにパルス ピッカーに同期した時間ゲートをかけることにより， APDの熱雑音を大幅に軽減した。

\section{DNA分子の近接場CARSイメージング}

試作したシステムにより, DNA分子の近接場CARS 亿 メージングを行った。アア゙ニン $(\mathrm{A})$ とチミン $(\mathrm{T})$ のみを含 むDNA分子 $(\operatorname{poly}(\mathrm{dA}-\mathrm{d} \mathrm{T}))$ をガラス基板上で数十ナノメー トルの大きさに凝集させた ${ }^{13)}$. 2色の励起光の振動数をそ れぞれ， $\omega_{1}=12710 \mathrm{~cm}^{-1}($ 波長 $=786.77 \mathrm{~nm})$ と $\omega_{2}=11373$ $\mathrm{cm}^{-1}(879.25 \mathrm{~nm})$ に合わせ, その振動数差 $\left(\omega_{1}-\omega_{2}\right)$ を 1337 $\mathrm{cm}^{-1}$ に固定した。これは, アデニンに特徴的なラマン活性 分子振動 (五員環伸縮)の固有振動数に一致する ${ }^{8}$. この振 動共鳴条件下でイメージングした後， $\omega_{2}$ を変化させ，振 動数差をどの分子振動にも共鳴しない $1278 \mathrm{~cm}^{-1}$ に合わせ て, 再び同様のイメージングを行った。このDNA試料の 自発ラマン散乱スペクトルをFig. 4に示す.

Fig. 5 (a), 5 (b) に, 共鳴条件下 $\left(\omega_{1}-\omega_{2}=1337 \mathrm{~cm}^{-1}\right)$ で 取得した近接場CARS像と, 同時取得したAFM像をそれぞ れ示す. Fig. 5 (a)では, 100 nm程度の大きさのDNAクラ スターが, CARS光で可視化できた。また，中央に $160 \mathrm{~nm}$ 程度離れて分布する二つのクラスターが, CARS像上で空 


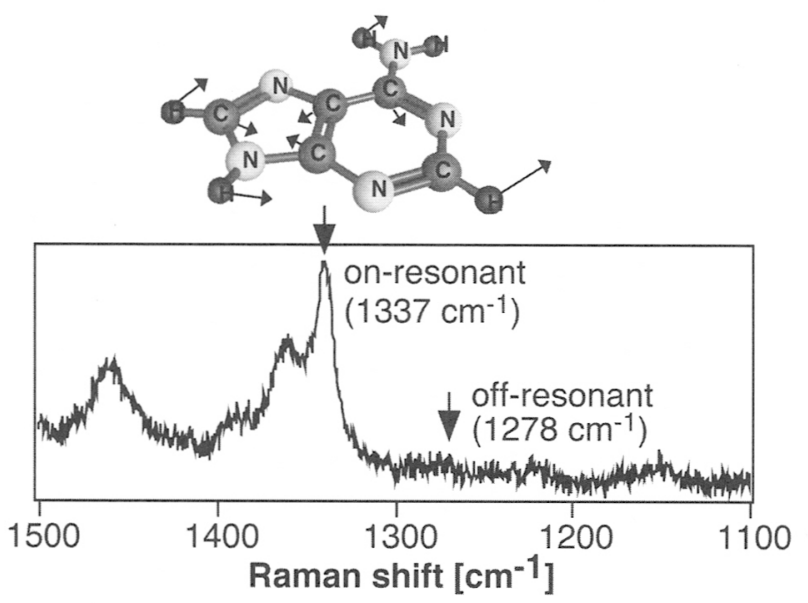

Fig. 4 A tip-enhanced spontaneous Raman spectrum of the DNA of poly (dA-dT).poly(dA-dT). The two frequencies adopted for our CARS imaging are indicated by the downward arrows. The Raman band at 1337 $\mathrm{cm}^{-1}$ can be assigned to the ring-stretching mode of adenine in the DNA.

間的に分離されている。これは，従来のCARS顕微鏡の二 点分解能(回折限界で制限される) を超えており, 銀チップ を用いたことで超解像を実現できたことを示している。 また，この像においてファーフィールドバックグラウン ドは全く見られなかったことから，CARSの非線形性によ り高コントラストなイメージングを実現したといえる。

Fig. 5 (c)-(d)は, 非共鳴条件 $\left(\omega_{1}-\omega_{2}=1278 \mathrm{~cm}^{-1}\right)$ に拈い て得られた光学像を異なるグレースケールで示したもの である. Fig. 5 (a) と比較して, CARS光強度は劇的に弱く なった。このことから，Fig. 5 (a)で得られた像が，励起 光の振動数差に依存する像, すなわち分子振動に共鳴し た像であることを確認した、銀チップによるCARSの増強 度は，別の実験で見積もったDNAのCARS効率との比較か ら, 単位体積あたりで106のオーダーと見積もられた。こ の増強度は，われわれや他のグループで報告されている 自発ラマンのチップ増強によるラマン増強度 $8,28,29)$ と比較
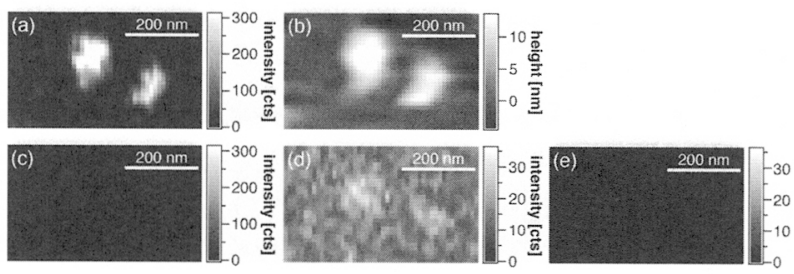

Fig. 5 CARS images of the DNA clusters. (a) Tip-enhanced CARS image at on-resonant frequency $\left(1337 \mathrm{~cm}^{-1}\right)$, and (b) the simultaneously obtained topographic image. (c) Tip-enhanced CARS image at the offresonant frequency $\left(1278 \mathrm{~cm}^{-1}\right)$. (d) The same image as (c) shown with a different gray scale. (e) CARS image of the corresponding area obtained without the silver tip. The scanned area is $500 \mathrm{~nm}$ by $300 \mathrm{~nm}$. The number of photons counted in 100 ms was recorded for one pixel. The acquisition time was $\sim 3$ minutes for the image. The average powers of the $\omega_{1}$ and $\omega_{2}$ beams were $30 \mu \mathrm{W}$ and $15 \mu \mathrm{W}$ at the $800 \mathrm{kHz}$ repetition rate.
して，1桁〜3桁大きい，2章で予想した，非線形性による 増強度の増大効果が示されたと言える。

非共鳴条件で得られた像(Fig. 5 (d))では，構造に一致 する信号がわずかに見られるが背景光にほぼ埋もれてい る。非共鳴条件下において構造に一致する信号が得られ る理由は, 次の 2 つが考えられる。1つ目は, 式(2)の非共 鳴項に起因する非共鳴バックグラウンドである。もちろ ん, 振動共鳴とは無関係なので, 非共鳴条件下でも観察 される，2つ目は，近接場光学顕微鏡においてたびたび問 題となる構造アーチファクトである ${ }^{30)}$ 。一方, Fig. 5 (d) の背景光は，Fig. 5 (a)でも同程度の強度で観察されたが， 銀プローブを基板から遠ざけ，同様のイメージングを 行ったところ，信号強度はほぼゼロであった(Fig. 5 (e)). これらのことから，この背景光はプローブの銀または基 板のガラスからの非線形発光によるものであると言え る。

さらに，本システムの空間分解能と検出限界を評価す るためにより微細な構造を観察した。試料としては， DNAのネットワーク構造を用いた。やはりアデニンとチ ミンのみを含んだDNA二重螺旋構造が十数本程度の束に なって，網目状に自己組織化したものである31)。構造の 高さは約 $2.5 \mathrm{~nm}$ 程度であり，これは一本のDNA二重螺旋構 造と同程度かやや大きい。この試料を，さきほどと同様 に共鳴および非共鳴の振動数条件でイメージングした (Fig. 6 (a)-(b)). DNAネットワークの微細構造がCARS光 でイメージングできた。これらの像の矢印で示した一行 のラインプロファイルを, Fig. 6 (c)に示す. チップを基 板から遠ざけて取得したラインプロファイルも併せて示 す。ここから明らかなように，非共鳴の条件下では構造 からの信号がほとんど得られず，チップを遠ざけると背 景光ともども信号強度はゼロになる。また，このライン プロファイルの右のピークの半值幅は $15 \mathrm{~nm}$ 程度であっ た。これは，これまでに我々がチップ増強の自発ラマン

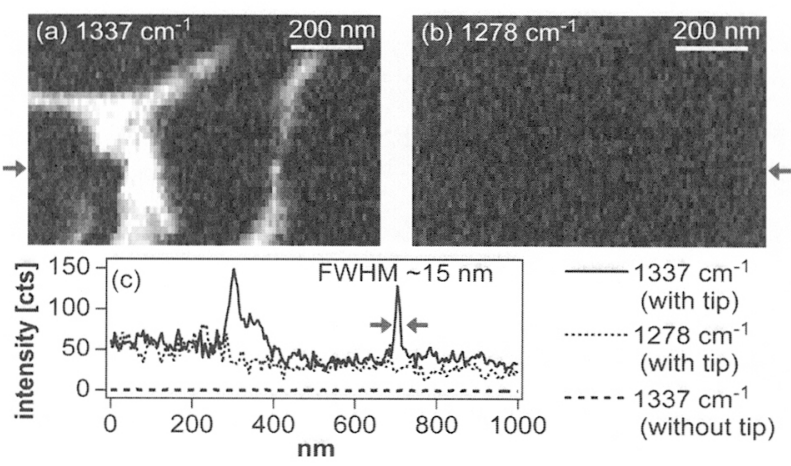

Fig. 6 CARS images of the DNA network. (a) Tip-enhanced CARS image at on-resonant frequency $\left(1337 \mathrm{~cm}^{-1}\right)$. (b) Tip-enhanced CARS image at the off-resonant frequency $\left(1278 \mathrm{~cm}^{-1}\right)$. (c) One dimensional line profiles of the row indicated by the solid arrows. The scanned area is $1000 \mathrm{~nm}$ by $800 \mathrm{~nm}$. The number of photons counted in $100 \mathrm{~ms}$ was recorded for one pixel. The acquisition time was $\sim 12$ minutes for the image. The average powers of the $\omega_{1}$ and $\omega_{2}$ beams were $45 \mu \mathrm{W}$ and $23 \mu \mathrm{W}$ at the $800 \mathrm{kHz}$ repetition rate. 
散乱で達成した空間分解能 $(\sim 30 \mathrm{~nm})^{8)}$ に比べて優れてい る.さらに，得られた空間分解能 $15 \mathrm{~nm}$ と, 構造の高さ2.5 nmから，信号に寄与するDNAの体積をゼプトリットル $(=$ $\left.1000 \mathrm{~nm}^{3}\right)$ のオーダーと見積もることができる．つまり， 現在の測定条件下でサブゼプトリットルの大きさのDNA を検出できることが明らかになった。

\section{5. おわりに}

金属チップによる局所電場増強効果を利用した近接場 CARS顕微鏡を提案し，DNA分子のCARSイメージングを 実現した。とくに，DNAネットワークのナノ構造をアデ ニンの分子振動 $\left(1337 \mathrm{~cm}^{-1}\right)$ で可視化し，およそ $15 \mathrm{~nm}$ の空 間分解能の空間分解能を達成した。近接場CARS顕微鏡の 今後の課題としては，空間分解能や検出感度のさらなる 向上が挙げられる。より微細な構造，あるいはより少な い分子数を観察するために必要となる。ただし，CARS強 度は分子数の 2 乗に比例するため，分子数を少なくしてい くと強度が急激に弱くなる．強度が分子数に比例する自 発ラマンに比べて信号が弱くなると考えられる。実際， 表面増強ラマン散乱 (SERS)について言えば，幾つかのグ ループはSERSによる単分子検出にも成功している32-34) しかし，ごく最近には表面増強CARS (SECARS)による単 分子検出という報告もあり ${ }^{35)}$ ，どちらが有利かについて はまだ議論の余地がある。このため，近接場CARS顕微鏡 と近接場自発ラマン顕微鏡の検出感度の定量的な比較も 今後の重要な課題の1つである.

いずれにしても，近接場CARS顕微鏡が強力なナノ分析 ツールであることには変わりはない．染色されていない 無色のDNA分子を，その分子振動だけで可視化できるの だから。この方法は，種々の核酸関連分子はもちろん， あらゆる種類の分子のイメージングに有効となる。単層 カーボンナノチューブなどのナノカーボン材料について はとくに，ラマン分光法がその分析ツールとして広く利 用されており 36,37$)$ ，これにナノ分解能を付加できればその 応用範囲は飛躍的に広がる12,38,39)。実際に我々のグループ には分析依頼の引き合いが多く来ている。ナノテクノロ ジーやナノサイエンスに従事する企業や大学の研究者た ちが，既存の方法では観察できなかったものを観察した り分析したりする方法として，近接場CARS顕微鏡あるい は近接場 (自発)ラマン顕微鏡に期待を寄せている。より高 感度，高空間分解能で且つ実用的なものにすべく，引き 続き検討と改良を重ねていきたい。

\section{参考文献}

1) S. Kawata (Ed.): Near-Field Optics and Surface Plasmon Polaritons (Springer, Berlin, 2001)

2) 森田清三編著：原子 · 分子の十ノ力学 (丸善2003)

3) Y. Inouye and S. Kawata: Opt. Lett. 19 (1994) 159.

4) Y. Inouye, N. Hayazawa, K. Hayashi, Z. Sekkat, and S. Kawata: Proc. SPIE 3791 (1999) 40.

5) N. Hayazawa, Y. Inouye, Z. Sekkat, and S. Kawata: Opt. Commun. 183 (2000) 333.

6) R. K. Chang and T. E. Furtak (Ed.): Surface Enhanced Raman Scattering (Plenum Press, New York, 1981).

7) M. Moskovits: Rev. Mod. Phys. 57 (1985) 783.

8) H. Watanabe, Y. Ishida, N. Hayazawa, Y. Inouye, and S. Kawata: Phys. Rev. B 69 (2004) 155418

9) N. Hayazawa, T. Yano, H. Watanabe, Y. Inouye, and S. Kawata: Chem. Phys. Lett. 376 (2003) 174.

10) A. Hartschuh, E. J. Sanchez, X. S. Xie, and L. Novotny: Phys. Rev. Lett. 90 (2003) 95503.

11) B. Pettinger, B. Ren, G. Picardi, R. Schuster, and G. Ertl: Phys. Rev. Lett. 92 (2004) 096101

12) N. Hayazawa, T. Ichimura, M. Hashimoto, Y. Inouye, and S. Kawata: J. Appl. Phys. 95 (2004) 2676.

13) T. Ichimura, N. Hayazawa, M. Hashimoto, Y. Inouye, and S. Kawata: Phys. Rev. Lett. 92 (2004) 220801.

14) H. Furukawa and S. Kawata: Opt. Commun. 148 (1998) 221.

15) T. Okamoto: in Ref. 1, p. 97.

16) N. Hayazawa, Y. Inouye, Z. Sekkat, and S. Kawata: J. Chem. Phys. 117 (2002) 1296.

17) A. Hartschuh, E. J. Sanchez, X. S. Xie, and L. Novotny: Phys. Rev. Lett. 90 (2003) 95503.

18) M. D. Levenson and S. S. Kano: Introduction to Nonlinear Optical Spectroscopy (Academic Press, Orlando, 1988).

19) T. Ichimura, N. Hayazawa, M. Hashimoto, Y. Inouye, and S. Kawata: J. Raman Spectrosc. 34 (2003) 651.

20) A. Zumbusch, G. R. Holtom, and X. S. Xie: Phys. Rev. Lett. 82 (1999) 4142.

21) M. Hashimoto, T. Araki, and S. Kawata: Opt. Lett. 25 (2000) 1768

22) M. Hashimoto and T. Araki: J. Opt. Soc. Am. A 18 (2001) 771.

23) J.-X. Cheng, A. Volkmer, and X. S. Xie: J. Opt. Soc. Am. B 19 (2002) 1363.

24) 河田 聡：超解像の光学 (日本分光学会測定法シリーズ38, 学 会出版センター，1999)

25）河田 聡, 井上 康志：応用物理 71 (2002) 653 .

26) M. Kerker and C. G. Blatchford: Phys. Rev. B 26 (1982) 4052.

27) N. Hayazawa, Y. Inouye, Z. Sekkat, and S. Kawata: Chem. Phys. Lett. 335 (2001) 369.

28) A. P. Sokolov, D. Mehtani, N. Lee, R. D. Hartschuh, A. Kisliuk, and M. D. Foster: J. Raman Spectrosc. (to be published)

29) B. Pettinger, B. Ren, G. Picardi, R. Schuster, and G. Ertl: Phys. Rev. Lett. 92 (2004) 096101.

30) B. Hecht, H. Bielefeldt, Y. Inouye, D.W. Pohl, and L. Novotny: J. Appl. Phys. 81 (1997) 2492

31) S. Tanaka, L. T. Cai, H. Tabata, and T. Kawai: Jpn. J. Appl. Phys. 40 (2001) L407.

32) S. Nie and S. R. Emory: Science 275 (1997) 1102.

33) K. Kneipp, Y. Wang, H. Kneipp, L. T. Perelman, I. Itzkan, R. R. Dasari, and M. S. Feld: Phys. Rev. Lett. 78 (1997) 1667.

34) M. Ishikawa, Y. Maruyama, J. Y. Ye, and M. Futamata: J. Luminescence 98 (2002) 81.

35) T.-W. Koo, S. Chan, and A. A. Berlin: Opt. Lett. 30 (2005) 1024

36) R. Saito, A. Jorio, J. H. Hafner, C. M. Lieber, M. Hunter, G. Dresselhaus, and M. S. Dresselhaus: Phys. Rev. B 64 (2001) 5312.

37) S. D. M. Brown, A. Jorio, M. S. Dresselhaus, and G. Dresselhaus: Phys. Rev. B 64 (2001) 3403.

38) P. Verma, K. Yamada, H. Watanabe, Y. Inouye, and S. Kawata: Phys. Rev. B 73 (2006) 045416.

39) T. Yano, P. Verma, Y. Inouye, and S. Kawata: Appl. Phys. Lett. in press. 